\title{
Training The Trainers: Parlate Italiano? An Experiential Exercise In International Human Resources
}

Karen Eastwood, Florida Gulf Coast University, USA

Monika Renard, Florida Gulf Coast University, USA

\begin{abstract}
This exercise was developed to teach students in an international management or human resource class the importance of international training. The students choose and learn some basic vocabulary in a foreign language and then develop and present an effective training module for those language skills. An example of one such module is described.
\end{abstract}

Keywords: International Training; International Experiential Exercises; International Human Resource Management

\section{INTRODUCTION}

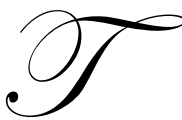

he increasing emphasis on a global business environment means that firms need to prepare their employees for both short- and long-term international assignments. The costs associated with placing home country employees, or expatriates, in these international posts have been projected at three to five times the base salary (Bennettt, Aston, \& Colquhoun, 2000). Unfortunately, there is an estimated U.S. expatriate failure rate in the 30\%-85\% range (Shen \& Edwards, 2004). The National Foreign Trade Council in 1994 estimated the cost of a poor international staffing decision to range from $\$ 200,000$ to $\$ 1.2$ million (Black, Gregersen, Mendenhall, \& Stroh, 1999; Swaak, 1995). Significantly, a failed expatriate is expensive not only because of the recruitment, selection, and placement costs, but more importantly in terms of the potential loss of face and trust within the host country. Studies have shown that all countries experience expatriate failures (Forster, 1997; Fukuda \& Chu, 1994; Stening \& Hammer, 1992; Tung, 1988).

\section{Importance Of Training International Managers.}

A major reason for expatriate failure is the inability of the international assignees and their families to adjust to the foreign environment (Global Relocation Services, 2005). Other causes of failure include inadequate cultural and language preparation, a lack of motivation, mistakes made in the selection process, personality difficulties, the inability to cope, and dissatisfaction with the quality of life in the foreign assignment (Briscoe \& Schuler, 2004; Lee, 2007; McCaughey \& Bruning, 2005).

One way to improve the success rate of expatriate placements is to provide extensive training prior to the international assignment and continued training within the host country (Brislin \& Yoshida, 1994; Forster, 2000; McCaughey \& Bruning, 2005; Trevin, 2003; Waxin \& Panaccio, 2005). It has been shown that pre-departure training can reduce expatriate failure rates dramatically. For example, Shell employees who were sent to Saudi Arabia without prior training experienced a $60 \%$ early return rate. However, with just three days of pre-departure training, that figure dropped to $5 \%$, and a six-day program dropped the early return rate to just $1.5 \%$ (Briscoe \& Schuler, 2004). Further, literature reviews of cross-cultural training find that the training is effective in facilitating success in expatriate assignments (Black \& Mendenhall, 1990; Littrell, Salas, Hess, Paley, \& Riedel, 2006).

Training for international assignments increases cultural sensitivity; reduces culture shock; fosters greater cross-cultural understanding; is seen as a cornerstone to successful international assignments; creates awareness of 
cultural differences and the influence of culture on behavior; increases managerial effectiveness; and improves the international assignee's competence as an intercultural communicator (Bennett et al, 2000; Jain \& Agrawal, 2005; Littrell, \& Salas, 2005; Stewart, 2002). Hofstede and Hofstede (2005) suggest various approaches to intercultural training, such as expatriate briefings, awareness training, and learning the local language. Harris and Moran (1999) emphasize the importance of covering topics that will facilitate the adjustment process, such as intercultural business skills; culture shock management; lifestyle adjustment; host-country daily living issues; local customs; and etiquette. In addition, they suggest language-learning strategies for pre- and post-arrival training. Language study not only facilitates an expatriate's ability to meet daily needs, it also opens the door to a deeper cultural understanding by demonstrating thought and behavioral patterns. Further, though language training is often crucial for intercultural adjustment, it is not necessary for the individual to become fluent. Rather, providing expatriates with the ability to exchange common courtesies will be appreciated as a demonstration of interest in the host nationals and their culture (Littrell \& Salas, 2005). Consequently, it is important to introduce students in international management classes to the experience of learning at least the rudiments of a new language.

\section{Importance Of Training The Trainers}

Using effective trainers is also an important ingredient in a successful program (Bennett, et al, 2000). To succeed as a multinational enterprise, human resource managers need to be prepared to develop and deliver training programs that will help their organizations achieve a competitive advantage in their global operations (Mendenhall, Jensen, Black, Gergersen, 2003). Students in international human resource or international management classes, therefore, must learn ways to become more effective trainers, especially for their international assignees. Yet, many students in international classes have no experience in developing any training programs, let alone more complex ones, such as those necessary in the international arena.

Training students in international human resources means helping them learn how to be effective trainers themselves. To facilitate an understanding of the role and importance of the cross-cultural trainer, we have developed an experiential exercise for students in an International Human Resource or an International Management course. As previously referenced, language skills have been identified as a success factor for expatriates. Therefore, in this exercise the students learn 100 words or phrases in a foreign language of their choice, and then develop a training module to train others in this language. Students learn basic vocabulary in a new language, but more importantly, they develop ways to engage their classmates in effective training methods.

\section{Cross-Cultural Training}

Cross cultural training (CCT) is the educative processes used to improve intercultural learning via the development of the cognitive, affective, and behavioral competencies needed for successful interactions in diverse cultures (Landis \& Brislin, 1996; Littrell et al, 2006; Morris \& Robie, 2001). CCT programs should provide expatriates with the knowledge and skills needed for (a) cross-cultural adjustment, (b) effective business performance, and (c) cross-cultural interactions (Littrell et al, 2006). Language training, one type of CCT, may help in all three of these important areas.

A successful CCT should take into account three key elements: needs of the expatriate, the customization of the content and design methodologies, and the program quality (Littrell et al, 2006). First, a needs analysis should be conducted to identify the pre-training strengths and weakness of the expatriate in relation to the desired behaviors. In the exercise presented, the instructor models doing a needs analysis by identifying which languages the students have familiarity with and what level of language learning experience each has. Optionally, the instructor may administer a pre-test quiz of the vocabulary words to determine their knowledge and to foster their understanding of the pretest-posttest training design.

For the customization of the content and design methodologies, training should be tailored to each expatriate's situation, and to meet the skill development needs. In the exercise described in this paper, customization is modeled by the choice of basic words; the involvement of students; the repetition and reinforcement of learning; and the experiential aspect of having students use their knowledge to train others (a learning-transfer measure). 
For program quality, in this exercise measures of training success are modeled by incorporating quizzes and a post-test. The post-test can be compared to the pre-test, so that students can verify that learning has occurred. Additionally, students can give their reactions to the learning of the words and to each training session as it is presented.

\section{THE EXERCISE: TRAINING THE TRAINERS}

The exercise includes three parts: 1. Students learn vocabulary in a foreign language. 2. Students learn how to design and develop a training module. 3. Students present their completed training module to the class. The exercise is generally accomplished in phases over the semester, to assure that students have enough time to learn the language and the training topics, and to present their modules.

\section{Part 1. Vocabulary}

This part starts toward the beginning of the course over one or two class periods, depending on how much in-class time the instructor can provide the students to work on their languages. Optionally, the instructor may wish to demonstrate a pre-test/post-test training design by having the students complete a pre-test of a selection of vocabulary words. See Appendix A for a sample key.

In the first class, students identify a language they would like to learn and teach, preferably one that they have never learned before. The instructor should tell the students to be mindful when they choose a language because they will have to learn to read, write, and speak in that language. Some groups may initially choose an exotic one, such as Japanese or Chinese, but then find that the resources are limited or the language is difficult to learn. Students will usually switch to a more accessible language when this occurs. The students are then formed into groups of about five to seven based on their chosen new language and the class size. Alternatively, the instructor may wish to form the groups and assign each group a different language. This approach may simplify the task for the instructor and limit the languages to a select few.

During this same class, the instructor provides a beginning list of key words and phrases, such as basic greetings, for interaction in another country. See Appendix B for a sample format for this list. The instructor may find that offering at least 50 initial words is helpful to the students. The class as a whole is then allowed to add words or phrases that they think are important. Many take these additions from phrase books in their languages, e.g. Eyewitness Travel Guides (2003). Involving the students in choosing the words helps with commitment and allows them to include words that might be more common or important to their generations. A total of 100 words and short phrases are chosen. These may be words that are used singularly, such as "Hello"; or they may be part of a phrase or sentence, such as "Where is the bathroom?" The focus in this exercise is on learning basic words rather than correct grammar. Since words are the building blocks of language, knowing more vocabulary, even if one's grammar is incorrect, will be helpful in international experience. However, phrases include some verb forms and basic sentence structure. If an instructor prefers more correct grammar, then sample sentences can be used instead, and the number of words reduced if desired, e.g., the exercise could be " 50 sentences in a new language."

In the same class day, or a subsequent one, students begin to translate the words and phrases and find the proper pronunciations. The instructor may bring a selection of foreign language phrase books or dictionaries to class so the students will be able to start the assignment. Alternatively, students may go to the library to work on this part of the assignment, or they may use an Internet translator (e.g., http://babelfish.altavista.com/). If classrooms have wireless connections, this last avenue would be particularly convenient. If time is a constraint, the instructor may elect to allow the students to begin translation in class and complete it on their own. Learning the pronunciation is generally done on the students' time; audiotapes are readily available at libraries and some phrase books contain pronunciation.

After the students have completed translating the English words into their chosen language, the instructor should get a copy of the list from each group to verify that the words are correct and consistent; and then modify the list if necessary. This allows the instructor to make corrections when synonyms are used, or to prevent errors due to 
the words being taken out of context. The instructor may wish to use the students' lists to develop test questions. (See Appendix A)

Though language learning is difficult for many English-speaking students in the U.S., those who are interested in international management are often motivated to do so. Furthermore, international students, whose second-language is English, often take these classes and can be a resource for other students. As an option, the instructor may encourage students to practice their foreign words in class by having the students say the word and its translation whenever the English word comes up in class. This reinforces their learning. (Since all students have the same word list, the instructor may purposely include the words in the lecture; pause to hear their replies; and then give a Hershey's Kiss for a correct word. This is another fun way to facilitate and reward their learning.) Another motivational tip is to have weekly quizzes on ten words from the list.

Based on social learning theory (Bandura, 1986), instructors should model the effective training development and presentations skills they want students to learn. Instructors should point out the behavior or technique they are modeling (perhaps the needs analysis), incorporate trainee involvement, pace the sessions, have the students practice their learning, and reward them for performance.

\section{Part 2. Design The Training Module}

After the students have had some chance to learn their languages, the training portion begins. The exercise now focuses on the design, activities, and format of the students' training module. Students are told that each group will have 30 minutes to train the rest of the class in its foreign language. They may decide to train all at once or divide it over two class days to allow students time to study the presented language between the two classes. The instructor should find out which option each group prefers and schedule the training sessions accordingly. The presentations are generally done toward the end of the semester.

In international management and human resource courses, there is generally a topic on training issues. Most textbooks used in these courses cover how to design, develop, and present basic training modules. To have students practice the actual task of designing training modules, and to get them to experience immediate feedback on their outcomes, the instructor should use "developing a language-facilitation module" as part of the training and development lecture. This will start them on the right path for their group presentation. If too little information is given in the text, or if this exercise is used in classes where training is not major topic, the instructor may wish to give a more detailed lecture.

Also, in this part students are given the training module assignment, e.g.: "Develop and present a Training Module to train the rest of the class on your chosen foreign language. Use information and guidance on training programs as presented in your text. In 30 minutes present an interesting, enjoyable, informative session where your classmates will develop familiarity with the new language." Instructors should be careful to include in the lecture, handout, or assignment, the aspects of developing and presenting a training module on which the students will be graded.

\section{Part 3. Present The Training Module}

A particularly enjoyable and effective language module that a student group (trainers) presented is described next. The trainers, who were teaching Italian, chose to divide the presentation over two class days. On the first day, the trainers handed out flash cards with the 100 Italian words or phrases on one side and the English translation on the other. Then the trainers went over each word, pronouncing it and having the students repeat the words after them. They asked the students to study the words before the next class period using the take-home flash cards and a translation handout.

On the second day, the trainers distributed Italian Word Bingo sheets with a $5 \times 5$ grid. Each sheet had a different selection of Italian words. In this modified Bingo game, the trainers drew out one word or phrase at a time from a bag with the 100 English words, and called each out. Students had to translate the word into Italian in order 
to find and mark the Italian word on the Bingo sheet. For markers, the trainers provided red, white and green jelly beans, representing the colors of the Italian flag. The first person to get Bingo won a prize of Italian chocolates (lots of calories in this course!)

\section{Student Reactions}

Students are enthusiastic about this experiential exercise/assignment. They responded positively to each phase: learning the languages, designing an effective training program, and teaching a foreign language. They found the language learning section difficult but fun, even though the words and phrases were basic. This underscores the value of teaching basic phrases. In addition, students said that having to train the class in the foreign language helped motivate them to learn their language, and caused them to study the words more seriously. Further, the students said that they enjoyed both designing creative training exercises and participating in the training modules developed by the other groups.

\section{CONCLUSION}

In sum, this exercise is an enjoyable, effective method to teach students the importance of cross-cultural training and the steps involved in the design and delivery of effective training programs. They begin to understand the importance of pre-training in the international assignment. Because the class is divided into groups, students have the opportunity to develop a language-training module and then practice their trainer skills with the other groups. In addition, they get to experience the learning process when they become the trainees of another group. By experiencing both sides of a training program, students are able to get and to give immediate feedback on the effectiveness of various training techniques. This experiential exercise allows the instructor to teach the students some basics of a foreign language; to model the presentation of a training module; to provide a venue where they can demonstrate their understanding of how to develop international training programs; and to help them gain the experience of delivering a training module for prospective expatriates.

\section{REFERENCES}

1. Bennett, R., Aston, A. \& Colquhoun, T. (2000). Cross-cultural training: A critical step in ensuring the success of international assignments. Human Resource Management, (39), 239-250.

2. Black, J.S., Gregersen, H.B., Mendenhall, M.E. \& Stroh, L.K. (1999) Globalizing people through international assignments. Addison-Wesley: Reading, Massachusetts.

3. Bandura, A. (1986). Social foundations of thought and action: A social cognitive theory. Englewood Cliffs, NJ: Prentice hall.

4. Black, J.S. \& Mendenhall, M. (1990). Cross-cultural training effectiveness: A review and a theoretical framework for future research. Academy of Management Review 15(1), 113-136.

5. $\quad$ Briscoe, D. \& Schuler, R. (2004). International Human Resource Management, 2nd ed. New York: Routledge.

6. Brislin, R. \& Yoshida, T. (1994). Intercultural communication training: An introduction. Thousand Oaks, CA: Sage.

7. Eyewitness Travel Guides. (2003). European phrase book. London: DK Publishing.

8. Landis, D. \& Brislin, R.W. (Eds). (1996). Handbook of intercultural training ( $2^{\text {nd }}$ ed.) Thousand Oaks, CA: Sage.

9. Lee, H. (2007). Factors that influence expatriate failure: An interview study. International Journal of Management. 24(3), 403-413.

10. Forster, N. (1997). The persistent myth of high expatriate failure rates: A reappraisal. International Journal of Human Resource Management, 8, 414-433.

11. Forster, N. (2000). Expatriates and the impact of cross-cultural training. Human Resource Management Journal, 10(3), 63-78.

12. Fukuda, K.J., \& Chu, P. (1994) Wrestling with expatriate family problems: Japanese experience in East Asia. International Studies of Management and Organization, 24(3) 36-47. 
13. Global Relocation Service. (2005). Global Relocation Trends 2005 Survey Report, GMAC Global Relocation Service Website. http://www.gmacglobalrelocation.com/insight_support/grts.asp (retrieved October 20, 2007).

14. Hofstede, G. \& Hofstede, G.J. (2005). Cultures and organizations: Software of the mind. New York: McGraw-Hill.

15. Jain, R. \& Agrawal, R. (2005). Indian and international perspectives on employee training practices: A trend report. South Asian Journal of Management, 12(1) 79-100.

16. Littrell, L.N., \& Salas, E. (2005). A review of cross-cultural training: Best practices, guidelines, and research needs. Human Resource Development Review, 4(3), 305-334.

17. Littrell, L.N., Salas, E., Hess, K.P., Paley, M. \& Riedel, S. (2006 ). Expatriate Preparation: A critical analysis of 25 years of cross-cultural training research. Human Resource Development Review, 5(3), 355388.

18. McCaughey, D., Bruning, N.S. (2005). Enhancing opportunities for expatriate job satisfaction: HR strategies for foreign assignment success. HR. Human Resource Planning, 28(4), 21-29.

19. Mendenhall, M.D. Jensen, R.J., Black, J.S. \& Gergersen, H.B. (2003). Seeing the elephant: Human resource management challenges in the age of globalization. Organizational Dynamics, 32(3), 261+.

20. Morris, M.A. \& Robie, C. (2001). A meta-analysis of the effects of cross-cultural training on expatriatre performance and adjustment. International Journal of Training and Development, 5, 112-125.

21. Shen, J. \& Edwards, V. (2004). Recruitment and selection in Chinese MNEs. The International Journal of Human Resource Management, 15(4,5) 814+

22. Stening, B.W. \& Hammer, M.R. (1992). Cultural baggage and the adaption of expatriate American and Japanese Managers. Management International Review, 32(1), 77-89.

23. Stewart, J. (2002). A blended e-learning approach to intercultural training. Industrial and Commercial Training, 34, (6/7) 269-271.

24. Swaak, R. (1995, November/December). Expatriate Failures: Too many, Too Much Cost, Too Little Planning. Compensation and Benefits Review, 47-55.

25. Trevin, S. (2003). International training: The training of managers for assignment abroad. Education \& Training, 45(8/9), 550-557.

26. Tung, R. (1987). Expatriate assignments: Enhancing success and managing failures. Academy of Management Executive, 1, 117-126.

27. Tung, R. (1988). Career Issues in International Assignments. The Academy of Management Executive, 2(3), 241-244.

28. Waxin, M. \& Panaccio, A. (2005). Cross-cultural training to facilitate expatriate adjustment: It works! Personnel Review, 34(1), 51-65.

\section{Appendix A-Sample Key}

\begin{tabular}{|c|c|c|c|c|c|}
\hline$\#$ & English & Spanish & Italian & French & German \\
\hline 1 & Hello & Hola & Ciao/Salve! & Bonjour/Salut & Hallo \\
\hline 2 & Good morning & Buenos dias & Buon giorno & Bonjour & Guten Morgen \\
\hline 3 & Good day & Buenas tardes & Buon giorno & Bonjour & Guten Tag \\
\hline 4 & Good evening & Buenas noches & buona sera & Bonsoir & Guten Abend \\
\hline 5 & Good night & Buonas noches & buona notte & Bonne nuit & Gute Nacht \\
\hline 6 & Goodbye & Adios & Arrivederci & Au revoir & Auf Wiedersehen \\
\hline 7 & Yes & $\mathrm{Si}$ & $\mathrm{Si}$ & Oui & $\mathrm{Ja}$ \\
\hline 8 & No & No & No & Non & Nein \\
\hline 9 & Please & Por favor & Per piaceri/ prego & S'il vous plait & Bitte \\
\hline 10 & Thank you & Gracias & grazie & merci & Danke \\
\hline 11 & $\mathrm{OK}$ & Vale & $\mathrm{OK}$ & D'accord & $\mathrm{OK}$ \\
\hline 12 & That's/ it's & Esta & $\mathrm{E}$ & C'est... & Das ist... \\
\hline 13 & That's fine. & Esta bien & Va bene & C'est bien & In Ordnung \\
\hline 14 & $\begin{array}{l}\text { How do you do, } \\
\text { pleased to meet you. } \\
\text { (idiomatic) }\end{array}$ & $\begin{array}{l}\text { ¿Que tal?, mucho } \\
\text { gusto }\end{array}$ & Piacere di conoscerla & $\begin{array}{l}\text { Enchante (de faire } \\
\text { votre connaissance) }\end{array}$ & Guten Tag, freut mich. \\
\hline
\end{tabular}




\begin{tabular}{|c|c|c|c|c|c|}
\hline \# & English & Spanish & Italian & French & German \\
\hline 15 & $\begin{array}{l}\text { How are you? } \\
\text { (idiomatic) }\end{array}$ & ¿Como esta usted? & Come sta? & Comment allez-vous? & Wie geht es Ihnen? \\
\hline 16 & I am & Estoy & Sono & Je suis & Ich bin \\
\hline 17 & Very well/fine & Muy bien & Benissimo & Tres bien & Sehr gut \\
\hline 18 & And you? & ¿Y usted? & E voi? & Et vous? & Und Ihnen? \\
\hline 19 & $\begin{array}{l}\text { My name is/ I am } \\
\text { called... (idiomatic) }\end{array}$ & Me llamo & Mi chiamo... & Je m'appelle... & Ich hei $\square \mathrm{e} . .$. \\
\hline 20 & $\begin{array}{l}\text { What is your name? } \\
\text { (idiomatic) }\end{array}$ & $\begin{array}{l}\text { ¿Como se llama } \\
\text { usted? }\end{array}$ & Come si chiama? & $\begin{array}{l}\text { Comment vous } \\
\text { appelez-vous? }\end{array}$ & Wie hei $\square$ en Sie? \\
\hline 21 & $\begin{array}{l}\text { This is... } \\
\text { (man/woman) }\end{array}$ & Este/esta es & Questo e/questa e & Voici... & Das ist ... \\
\hline 22 & Excuse me! & Perdon! & Scusi! & Pardon! & Entschuldigung! \\
\hline 23 & $\begin{array}{l}\text { Can you? } \\
\text { Could you? }\end{array}$ & ¿Puede? & Potrebbe? & Pouvez-vous? & $\begin{array}{l}\text { Konnen Sie? } \\
\text { Konnten Sie? }\end{array}$ \\
\hline 24 & To tell & Decir & Dire & Dire & Sagen \\
\hline 25 & Can you tell me? & ¿Puede decirme? & Potrebbe dirmi? & Pouvez-vous me dire? & $\begin{array}{l}\text { Konnen Sie mir } \\
\text { sagen? }\end{array}$ \\
\hline 26 & Can you show me? & $\begin{array}{l}\text { ¿Puede usted } \\
\text { demostrarme? }\end{array}$ & Potete mostrarmi? & $\begin{array}{l}\text { Pouvez-vous me } \\
\text { montrer? }\end{array}$ & $\begin{array}{l}\text { Konnen Sie mir ... } \\
\text { zeigen? }\end{array}$ \\
\hline 27 & Can you help me? & ¿Puede ayudarme? & Puo aiutarmi? & Pouvez-vous m'aide? & $\begin{array}{l}\text { Konnen Sie mir } \\
\text { helfen? }\end{array}$ \\
\hline 28 & Can I/May I? & ¿Puedo? & Potrei? & Pourraise-je? & Kann ich? \\
\hline 29 & May/Can I have...? & ¿Puedo tiene...? & Potrei avere...? & $\begin{array}{l}\text { Est-ce que je pourrais } \\
\text { avoir...? }\end{array}$ & Kann ich ... haben? \\
\hline 30 & Do you have...? & ¿Tienen...? & Avete...? & Avez-vous...? & Haben Sie...? \\
\hline 31 & Would you like a ...? & ¿Quiere un/una...? & Vorrebbe un/una...? & $\begin{array}{l}\text { Est-ce que vous } \\
\text { voulez un/une...? }\end{array}$ & $\begin{array}{l}\text { Mochten Sie } \\
\text { einen/eine/ein ...? }\end{array}$ \\
\hline 32 & $\begin{array}{l}\text { Would you like } \\
\text { (to)...? }\end{array}$ & ¿Le gustaria...? & Le piacerebbe...? & $\begin{array}{l}\text { Est-ce que vous } \\
\text { voulez...? }\end{array}$ & Mochten Sie...? \\
\hline 33 & Is there... & ¿Наy...? & $\mathrm{C}^{\prime} \mathrm{e} \ldots ?$ & Est-ce qu'il y a...? & Gibt es...? \\
\hline 34 & Is there $\ldots$ here? & ¿Hay....aqui & $\mathrm{C}^{\prime} \mathrm{e} \ldots ?$ & Est-ce qu'il y a ....ici? & Gibt es ... hier? \\
\hline 35 & What & Que & Che & Qu'est-ce que & Was \\
\hline 36 & What 's that? & ¿Que es eso? & Che cos'e? & Qu'est-ce que c'est? & Was ist das? \\
\hline 37 & How much is it? & ¿Cuanto es? & Quanto costa? & Combien ca coute? & Was kostet das? \\
\hline 38 & Where & donde & Dove & $\mathrm{Ou}$ & Wo \\
\hline 39 & Where is the ... & ¿Donde esta el/la..? & Dov'e il/la...? & Ou est le/la...? & Wo ist der/die/das...? \\
\hline 40 & I am from ... & Soy de... & Sono di... & Je viens de... & Ich bin aus... \\
\hline 41 & I understand. & Comprendo & Capisco & Je comprends & Ich verstehe \\
\hline 42 & I don't understand. & No comprendo & Non capisco & Je ne comprends pas & Ich verstehe nicht \\
\hline 43 & Do you speak ... & ¿Usted habla ...? & Parlate ...? & Parlez-vous ...,? & Sprechen Sie... \\
\hline 44 & English & Inglese & Inglese & Anglais & Englisch \\
\hline 45 & I speak ... & Hablo & Parlo & Je parle & Ich spreche... \\
\hline 46 & I can't speak ... & No hablo ... & Non parlo ... & Je ne parle pas ... & Ich spreche keine ... \\
\hline 47 & I don't know & No se & Non so & Je ne sais pas & Ich wei $\square$ nicht. \\
\hline 48 & (the given language) & Espanol & Italiano & Francais & Deutch \\
\hline 49 & Write down & Anote & Scriva & Notez & Notieren \\
\hline 50 & It & Lo & Lo & $\mathrm{Le} / \mathrm{la}$ & Es \\
\hline 51 & $\begin{array}{l}\text { Please write it down } \\
\text { for me. }\end{array}$ & $\begin{array}{l}\text { Anótelo por favor para } \\
\text { mí. }\end{array}$ & $\begin{array}{l}\text { Annotilo prego per } \\
\text { me. }\end{array}$ & $\begin{array}{l}\text { Veuillez l'écrire pour } \\
\text { moi. }\end{array}$ & $\begin{array}{l}\text { Notieren Sie es bitte } \\
\text { für mich. }\end{array}$ \\
\hline 52 & I like... & Me gusta... & Mi piace... & J'aime/j'adore... & Ich mochte ... gern \\
\hline 53 & $\begin{array}{l}\text { I like music and } \\
\text { concerts }\end{array}$ & $\begin{array}{l}\text { Tengo gusto de } \\
\text { música y de } \\
\text { conciertos. }\end{array}$ & $\begin{array}{l}\text { Gradisco la musica et } \mathrm{i} \\
\text { concerti. }\end{array}$ & $\begin{array}{l}\text { J'aime la musique et } \\
\text { les concerts. }\end{array}$ & $\begin{array}{l}\text { Ich mag Musik und } \\
\text { Konzerte. }\end{array}$ \\
\hline 54 & Dancing & De bailar & Ballare & Danser & Tanzen \\
\hline 55 & Sports & Los deportes & Sport & Sports & Sport \\
\hline 56 & Theatre & del teatro & il teatro & le théâtre & Theater \\
\hline
\end{tabular}




\begin{tabular}{|c|c|c|c|c|c|}
\hline$\#$ & English & Spanish & Italian & French & German \\
\hline 57 & Nightlife & del nightlife. & il nightlife & Vie nocturne & Nachtleben \\
\hline 58 & Skiing & de esquiar. & sciare & skier & Ski fahren. \\
\hline 59 & I don't like... & No me gusta el/la... & Non mi piace... & Je n'aime pas... & Ich mag... nicht gern \\
\hline 60 & Do you like ...? & ¿Le gusto...? & Le piace...? & Aimez-vous...? & Mochten Sie...? \\
\hline 61 & What would you like? & ¿Que quiere? & Cosa desidera? & Qu'est-ce que vous? & Was mochten Sie? \\
\hline 62 & To drink & Beber & De bere & Boire? & Trinken \\
\hline 63 & $\begin{array}{l}\text { What would you like } \\
\text { to eat }\end{array}$ & $\begin{array}{l}\text { ¿Qué usted tiene gusto } \\
\text { de comer? }\end{array}$ & $\begin{array}{l}\text { Che cosa gradite } \\
\text { mangiare? }\end{array}$ & $\begin{array}{l}\text { Que aimez-vous } \\
\text { manger? }\end{array}$ & $\begin{array}{l}\text { Was wurden Sie } \\
\text { mögen essen? }\end{array}$ \\
\hline 64 & ...To do & ...de hacer & $\ldots$ fare & ...faire & ...Tun \\
\hline 65 & ...To see & ...de ver & ...vedere & ...voir & ...sehen \\
\hline 66 & I would like... & Queria... & Vorrei... & Je voudrais ... & Ich mochte... \\
\hline 67 & Nothing, thanks & Nada, gracias & Niente, grazie & Rien, merci & Nichts, danke. \\
\hline 68 & Cheers! & Salud! & Alla salute/ cin cin! & Sante! & Prost! \\
\hline 69 & Where & Donde & Dove & $\mathrm{Ou}$ & Wo \\
\hline 70 & $\begin{array}{l}\text { Where would you like } \\
\text { to go? }\end{array}$ & $\begin{array}{l}\text { ¿Donde usted tienen } \\
\text { gusto de ir? }\end{array}$ & $\begin{array}{l}\text { Dove voi gradiscono } \\
\text { andare? }\end{array}$ & Où vous aiment aller? & $\begin{array}{l}\text { Wo mochten Sie } \\
\text { gehen? }\end{array}$ \\
\hline 71 & I have... & Tengo & Ho & J'ai & Ich habe \\
\hline 72 & I am thirsty & Tengo sed. & Sono assetato. & J'ai soif. & Ich habe dirst. \\
\hline 73 & I am hungry & Tengo hambre. & Sono affamato. & J'ai faim. & Ich habe hunger. \\
\hline 74 & (the) Breakfast & El desayuno & La colazione & Le petit dejeuner & (das) Fruhstuck \\
\hline 75 & (the) Lunch & Almuerzo & Pranzo & Le dejeuner & (das) Mittagessen \\
\hline 76 & (the) Dinner & La cena & La cena & Le diner & (das) Abendessen \\
\hline 77 & (the) Check, please & La cuenta, por favor & Il conto, per favor & La note, s'il vous plait & Zahlen, bitte \\
\hline 78 & Where do I pay? & ¿Donde se paga? & Dove si paga? & Ou faut-il payer? & Wo ist die Kasse? \\
\hline 79 & I'll pay & Pagare & Pago & Je payerai & Ich zahle \\
\hline 80 & Credit card & Tarjeta (de credito) & Carta di credito & Carte de credit & Kreditkarte \\
\hline 81 & $\begin{array}{l}\text { I will pay by credit } \\
\text { card }\end{array}$ & $\begin{array}{l}\text { Pagare con tarjeta (de } \\
\text { credito) }\end{array}$ & $\begin{array}{l}\text { Pago con la carta di } \\
\text { credito }\end{array}$ & $\begin{array}{l}\text { Je payerai avec une } \\
\text { carte de credit }\end{array}$ & $\begin{array}{l}\text { Ich zahle mit } \\
\text { Kreditkarte }\end{array}$ \\
\hline 82 & $\begin{array}{l}\text { Do you take credit } \\
\text { cards? }\end{array}$ & $\begin{array}{l}\text { ¿Puedo pagar con } \\
\text { tarjeta de credito? }\end{array}$ & $\begin{array}{l}\text { Accette carte di } \\
\text { credito? }\end{array}$ & $\begin{array}{l}\text { Acceptez-vous les } \\
\text { cartes de credit? }\end{array}$ & $\begin{array}{l}\text { Akzeptieren Sie } \\
\text { Kreditkarten? }\end{array}$ \\
\hline 83 & I'll take it. & Me lo llevo. & Lo prendo & Je le prends & Ich nehme es. \\
\hline 84 & Where do I find...? & ¿Dónde encuentro ...? & Dove trovo...? & $\begin{array}{l}\text { Pouvez-vouz me dire } \\
\text { ou se trouve...? }\end{array}$ & Wo finde ich...? \\
\hline 85 & Where is...? & ¿Donde esta & Dov'e... & Ou est... & Wo ist...? \\
\hline 86 & (A) Taxi & (un) Taxi & (un) Taxi & (un) Taxi & (ein) Taxi \\
\hline 87 & The restroom/toilet & Il servicio & La toilette & La toilette & Die toilette \\
\hline 88 & The bus station & $\begin{array}{l}\text { el término de } \\
\text { autobuses }\end{array}$ & l'autostazione & la gare routière & den Busbahnhof \\
\hline 89 & The train station & la estación de tren & la stazione di treno & la station de train & die Zugstation \\
\hline 90 & The airport & el aeropuerto & l'aeroporto & l'aéroport & der Flughafen \\
\hline 91 & The beach & la playa & la spiaggia & la plage & der Strand \\
\hline 92 & A restaurant & el restaurante & il ristorante & Un restaurant & die Gaststätte \\
\hline 93 & An internet cafe & un Internet café & Internet caffè & Internet café & Internet Kaffee \\
\hline 94 & The department store & el almacén grande & il grande magazzino & grand magasin & $\begin{array}{l}\text { der Abteilung } \\
\text { Speicher }\end{array}$ \\
\hline 95 & The Hotel & el hotel & L'albergo/l'hotel & L' hotel & Das Hotel \\
\hline 96 & $\begin{array}{l}\text { Do you have movies } \\
\text { in English? }\end{array}$ & $\begin{array}{l}\text { ¿Usted tiene películas } \\
\text { en inglés? }\end{array}$ & Avete film in inglese? & $\begin{array}{l}\text { Avez-vous des films } \\
\text { en anglais? }\end{array}$ & $\begin{array}{l}\text { Haben Sie Filme in } \\
\text { den englischen? }\end{array}$ \\
\hline 97 & With English subtitles & $\begin{array}{l}\text { Con subtitulos } \\
\text { ingleses }\end{array}$ & $\begin{array}{l}\text { Con i sottotitoli } \\
\text { inglesi }\end{array}$ & $\begin{array}{l}\text { Dan des sous-titres } \\
\text { anglais }\end{array}$ & $\begin{array}{l}\text { Mit englischen } \\
\text { Untertiteln? }\end{array}$ \\
\hline 98 & $\begin{array}{l}\text { Do you have movies } \\
\text { in English or with } \\
\text { English subtitles? }\end{array}$ & $\begin{array}{l}\text { ¿Usted tiene películas } \\
\text { en ingleses o con } \\
\text { subtítulos ingleses? }\end{array}$ & $\begin{array}{l}\text { Avete film in inglese o } \\
\text { con i sottotitoli } \\
\text { inglesi? }\end{array}$ & $\begin{array}{l}\text { Avez-vous des films } \\
\text { dans anglais ou avec } \\
\text { sous-titres anglais? }\end{array}$ & $\begin{array}{l}\text { Haben Sie Filme in } \\
\text { den englischen oder } \\
\text { mit englischen } \\
\text { Untertiteln? }\end{array}$ \\
\hline 99 & Beer & Una cerveza & La birra & De la biere & Bier \\
\hline 100 & Another beer & Mas cerveza & Ancora birra & Plus de bierra & Noch ein Bier \\
\hline
\end{tabular}




\section{Appendix B-Sample Word List Format}

\section{Language Skills (100 words and phrases in your chosen foreign language)}

You must learn to speak, read, and write 100 words and phrases and be able to understand and respond to them in the language. In class we will modify the list to add words of your choice to the list and/or remove those that you do not want to learn, to make a total of 100 . Here is an example in German:

\begin{tabular}{|l|l|l|l|}
\hline$\#$ & Word/Phrase & Written Translation (Use polite forms) & Pronunciation \\
\hline 1 & Hello & Hallo & hallo \\
\hline 2 & Good morning & Guten Morgan & Gooten morgen \\
\hline 3 & Good day & Guten Tag & Gooten tahk \\
\hline 4 & Good evening & Guten Abend & Gooten ahbent \\
\hline 5 & Good night (going to bed) & Gute Nacht & Gootuh naKHt \\
\hline 6 & Goodbye & Auf Wiedersehen & Owf veeder-zayn \\
\hline 7 & Yes & Ja & Ya \\
\hline 8 & No & Nein & Nine \\
\hline 9 & Please & Bitte & Bittuh \\
\hline 10 & Thank you & Danke & Dankuh \\
\hline
\end{tabular}

\section{NOTES}


NOTES 